\title{
The Elementary Sch00l Teacher
}

\author{
FEBRUARY, I 9 I I
}

\section{COMMUNITY ARITHMETIC FOR THE SEVENTH AND EIGHTH GRADES}

WALTER W. HART

University of Wisconsin, Madison, Wisconsin

\section{INDEFINITE AIM IN THESE GRADES}

The course of study in mathematics for the seventh and eighth grades has been in an unsettled state for a long time. There has been and is little agreement in regard to the content of the curriculum, not to mention methods of instruction. Some courses contain no algebra or generalized arithmetic and no geometry, except the traditional work in the mensuration of certain plane and solid figures; on the other hand, there are courses at the other extreme in which the major portion, of the time in the eighth grade is devoted to algebra. The courses have had the catch-all character, consisting of a variety of topics lacking unity. The work has been criticized especially as lacking social meaning; many of the topics commonly given cannot be said to possess much direct or even remote meaning for the pupils, as an example of which may be mentioned cube root which is still taught in some schools, and such a topic as stocks and bonds, which, while relating to current business practice, is usually carried to such length as to lose most of the pupils. It has even been suggested that the instruction in the lower grades is more effective than that in the upper grades because the teachers in these lower grades know better what they are trying to accomplish. Without intending to join in any statement regarding the relative efficiency. 
of the teaching, this may be said, that in the first six grades the dominant mathematical purpose is to put the pupils in possession of the mechanics of the subject, to give them control over the essential number facts and processes and the ordinary tables of denominate numbers, whereas in the two upper grades there is no such clear-cut purpose in evidence.

\section{THE SOCIAL AIM OF EDUCATION}

In the meantime the social function of the work of the elementary grades has become a recognized factor in shaping the courses of study of the other studies. It is quite generally agreed that the school should bring the pupils into contact with matters of interest in their own community, always with the reservation that the materials of teaching should come within the scope of the children's power and interest. The term community is to be interpreted here in a broad way, extending gradually from the home to the town and state and then to the country at large.

\section{TWO AIMS FOR UPPER GRADE MATHEMATICS}

In view of the foregoing, the following two aims may properly be accorded a prominent place in determining the character of the mathematics work in the seventh and eighth grades: first, to maintain and increase efficiency in the fundamentals of arithmetic as taught in the earlier grades; second, to aid in the effort to give the pupils some insight into the life of the community in which they are to have a part. On the strictly mathematical side, it is important that the power the pupils have gained in the essentials of arithmetic shall be "conserved" and increased through appropriate drill. Whatever else of mathematical product the public may want of their schools, they unite in expecting that the graduates of the grammar grades shall be reasonably rapid and accurate in the fundamental operations of arithmetic, especially with such numbers as occur in daily life. Such skill is the product of persistent, well-directed drill; it is because of the neglect of such drill in the upper grades that much of the criticism of 
the mathematics work is thoroughly justified. This drill work becomes especially necessary if the children are to retain their acquaintance with and become skilful in the manipulation of fractions. In regard to the second aim, it is beginning to be recognized that the mathematics must contribute its share of "social insight," to use a phrase of Professor Suzzallo's. This statement does not imply that in the earlier work also this should not be one of the aims; but, in the case of the upper grades, this aim seems to afford the unifying principle which has been so noticeably lacking. The pupils have been taught the essentials in the lower grades; they are about to leave school, many of them permanently, and should now have their attention turned toward the social whole of which they form a part. What better principle of selection of material for mathematics work can there be than this?

This doctrine meets with quite general approval; it is the practice of it which causes difficulty, a difficulty which arises from the fact that the character of drill necessary cannot be entirely placed in book form, and secondly, that it is unlikely that publishers will place upon the market a book which is designed to meet the needs of one community.

The purpose of this article is to call attention to an attempt to put this theory into practice. It will become clear that the general plan might be followed in any other community, but that the material used in the classroom would have to be selected to fit the conditions of the particular community served.

\section{THE PLACE AND CONDITIONS}

In the Indianapolis schools, the classes are organized on a half-year basis; thus there is a $7 \mathrm{~B}$, a $7 \mathrm{~A}$, an $8 \mathrm{~B}$, and an $8 \mathrm{~A}$ grade, in the order indicated. The course of study called for continued drill upon the essentials, as well as for attention to certain new topics. This drill was expected to be both abstract and concrete, but there was no specification as to the material to be used, except that it should be simple, modern, and within the experience of the children. It was likely to be of a miscellaneous sort, a practice which is unwise owing to the tend- 
ency to scatter attention. Considerable time was being devoted to algebra. It was decided to systematize the drill work, to give it definite local meaning, and, in order to get additional time for it, to cut down the work in algebra. The modified work was introduced in grade $7 \mathrm{~A}$ and above.

\section{v. PLAN FOR GRADE 7A}

For this grade the problems were grouped under the general topic "Problems of the Home," with the following subtopics: (a) grocery, meat market, and department store problems; (b) making change; $(c)$ cost of heating and lighting the home; $(d)$ cost of furnishing the home.

The set $(a)$ consists of the problems which customers and clerks must solve daily. The problems are grouped so as to direct attention for a time toward grocery problems, then toward meat-market problems, etc. The material was collected by a committee of teachers from local tradesmen. The result is a collection of problems involving usual buying quantities under local conditions. Current prices are to be used and the problems are to be solved mentally as a rule. Some examples follow :

\section{MEAT MARKET-SET A}

I. Find the cost of a chicken weighing $3^{\mathrm{T} / 2} \mathrm{lbs}$; $4 \mathrm{lbs}$; $4^{\mathrm{T} / 4} \mathrm{lbs}$; $4^{\mathrm{T} / 2} \mathrm{lbs}$.

2. Find the cost of $\mathrm{I}^{\mathrm{I} / 2} \mathrm{lbs}$. of pork chops; $2 \mathrm{lbs}$; $2 \mathrm{~T} / 4 \mathrm{lbs}$; $3 \mathrm{lbs}$; $2 \mathrm{~T} / 2$ lbs.

3. Find the cost of a piece of bacon weighing 2 lbs.; $21 / 4 \mathrm{lbs}$; $23 / 4 \mathrm{lbs}$.

4. Find the cost of a piece of ham weighing $5 \mathrm{lbs}$; $6 \mathrm{lbs}$.; $6 \mathrm{r} / 4 \mathrm{lbs}$; $63 / 4$ lbs.; 7 lbs.

\section{MEAT MARKET-SET B}

I. How much lard should be given for Io cents? I5 cents? 20 cents? 25 cents? 30 cents?

2. How much sirloin steak should be given for io cents? 20 cents? 25 cents? 30 cents? etc.

3. How much in weight should be given to a woman asking for a rib roast which will cost 35 cents? 40 cents? 45 cents? 59 cents? etc.

4. How much boiled ham should be given for Io cents? I5 cents? 20 cents? 25 cents? etc.

$$
\text { GROCERY-SET C }
$$

I. Find the cost of $1 / 2 \mathrm{lb}$. of American cheese; of cream cheese; of Swiss cheese. 
2. Find the cost of $1 / 2 \mathrm{pk}$. potatoes; of a small measure of potatoes.

3. Find the cost of $1 / 4 \mathrm{lb}$. of tea; of $1 / 2 \mathrm{lb}$.

4. Find the cost of 2 bars of laundry soap; of three bars; of 5 bars.

GROCERY-SET D

I. Find the amount of rice to be given for I5 cents; 20 cents; 25 cents; etc.

2. Find the amount of tea to be given for 15 cents; 20 cents; 25 cents; etc.

3. Find the amount of pepper, allspice, cinnamon, cloves, etc., to be given for 5 cents; Io cents.

4. Find the amount of shelled almonds, pecans, walnuts, to be given for 5 cents; Io cents; 15 cents; etc.

GROCERY-SET E

I. Get together a list of supplies such as might be ordered by a family on each of the six days of a week. Have the bills for these made out on slips prepared like those used in the market. Have the total figured up daily and at the end of the week.

2. A woman ordered the following goods over the telephone: 25 cents worth of granulated sugar; Io cents worth of corn meal; a 35 cent porterhouse steak; Io cents worth of figs; I5 cents worth of cheese. Make out the sale slip for the order, fill in the amount of each article to be given for the money; find the total of the bill and the amount of change which the delivery boy must give the woman if she pays him with a $\$ 5.00$ bill.

GROCERY-SET F. ECONOMICAL PURCHASING

I. Compare the cost per pound of sugar bought by the pound with the cost when bought by the 25-pound sack.

2. Compare the cost of laundry soap when bought by the bar and when bought by the box; when bought by the quarter's worth.

3. A housekeeper having canned a bushel of peaches, wishes to know the cost per can. Find it if she used a bushel of peaches, 9 lbs. of sugar, Ioo $\mathrm{ft}$. of gas, and 15 Mason jars. Compare this cost with the current price for a can of peaches at the store.

The department-store section consists of a list of various kinds of ribbons, laces, silks, embroidery, and trimming materials, with current selling prices and selling quantities. These items were selected because the dealings in them are usually in small quantities, almost always involving computation with fractions. The data was obtained direct from the local stores. The managers were entirely willing to co-operate. They said 
that the average customer and many otherwise very desirable clerks were unable to obtain with any degree of certainty the cost of such purchases. Incidentally there is no small gain to the school system in having the business men know that the school is making a serious effort to meet such a situation. A few examples follow:

I. Baby ribbon, 2 cents, $3^{\mathrm{T} / 2}$ cents per yard; I9 cents, 32 cents per bolt.

Hair ribbon, $5^{\prime \prime}$ to $7^{\prime \prime}$ at to cents, I9 cents, 25 cents, 35 cents, 59 cents per yd. Quantities usually bought: I, II $1 / 2,11 / 4,133 / 8,2,2 \frac{1}{4} 4$ yds.

Shoe ribbon, at to cents and 18 cents. Quantity bought: for 3-eyelet shoe $\mathrm{I} 1 / 2 \mathrm{yds}$; for 4 -eyelet shoe $\mathrm{I} 3 / 4 \mathrm{yds}$; for 5 -eyelet shoe $2 \mathrm{yds}$.

2. Lace-cluny, imitation: $3 / 4$-inch at io cents; $I^{1} / 2$-inch at $121 / 2$ cents; $3^{\mathrm{T} / 2}$-inch at 19 cents and 25 cents; real: $3 / 4^{\text {-inch }}$ at 25 cents; $3^{\mathrm{T} / 2 \text {-inch at }}$ 50 cents and 59 cents.

And thus for the various items this infurmation is given. It is to be used in the making of problems. Also the following problems were given; they were taken direct from the canceled saleslips in one store:

Find the cost of $5 / 8$ yd. of lace at $\$ 19.50$ per yard; find the cost of $183 / 4$ yds. of muslin at $\$ 1.12 \mathrm{I} / 2$ per yd.; $183 / 4$ yds. of crepe at $\$ 1.25$ per yd.; $4^{\mathrm{T}} / 2$ yds. of gingham at $63 / 4$ cents per yd.; $83 / 4$ yds. of gingham at $7 \frac{1}{2}$ cents per yd.

For written work the following type of problem is included:

Bought 4 yds. of china silk at 49 cents a yd.; 8 yds. of cluny lace at 59 cents; $7 / 8$ yd. net at 75 cents; and 18 yds. of ribbon at 5 cents for a waist. What did the material for the waist cost?

As to the effect of this sort of work, some may object that while this is good correlation with domestic science it will not prove of interest to the boys; this may be true of the department-store problems. However, for both boys and girls these problems come very near to satisfying the present demand for school material which has vocational value and practical value. It is pertinent to point out that the average problems used in connection with the application of interest to business seem designed to meet the interests of the boys and not so much so those of the girls. In the case of the market.problems, it may be objected that the work is too simple; that it belongs 
in the fifth grade with fractions. Any of us will admit the need of constant review on fractions, and then besides, the pupils are getting more out of it than arithmetical skill. To illustrate, they brought saleslips from home and told of their watchfulness in purchasing for the family; one girl said that she had made the butcher give her another chop when she found him failing to give full weight; one boy told of adding up the weekly bill from the grocer and of finding a mistake on it. The work was real to them.

Under the topic "making change," the pupils are taught the addition method which is now commonly used in the stores. Under the topic "Cost of Heating and Lighting the Home," certain problems are introduced which give drill upon the local rates for coal, gas, and electricity.

\section{PLAN FOR GRADE 8B}

For Grade $8 \mathrm{~B}$, the problems are grouped under the topic "Problems Relating to the Industries of the City and State," with the following sub-topics: (a) manufacturing interests of Indianapolis; $(b)$ manufacturing interests of Indiana; (c) problems of certain lines of work; some railroad problems; some foundry problems; buying and selling paper; paying employees.

The first two sets are based upon the United States Census Reports, and the others were gathered in the city. They are designed to give the pupils an idea of these activities of their own community, of the number of employees, of the wages paid. They are expected to appeal to the vocational interest which should be growing at this time, and to show how arithmetic enters into the daily life of some of the workmen. A few examples will be given. Appropriate statistics are given to enable the pupils to solve the following problems:

Find the total number of wage-earners in 1900, and in 1905; find the total amount of wages paid in both years; find the total cost of manufacture in both years; find the total value of the manufactured products; find the total profits in each year and the per cent of profit; find the average wages paid in both years; compare the wages of the city wage-earnef with those of the wage-earner in the state at large; what 
percentage of the manufacturing establishments of Indiana are located in Indianapolis? What percentage of the manufactured products were made in Indianapolis?

It will be noticed that these problems involve about all of the essential processes, so that as review drill-work they are effective.

In a railroad shop running from 6:30 A.M. to 5:I5 P.M., with $3 / 4$-hour off for lunch, what will a boy earn in one day at $12^{1 / 2}$ cents per hour?

How many pieces 8 inches long can be cut from an iron bar 29 inches long, if $1 / 4$ inch is wasted on each cut? Illustrate by a drawing, assuming that the original bar had the dimensions $I^{\prime \prime} \times I^{\prime \prime} \times 29^{\prime \prime}$.

A brass foundry has to make 72 lbs. of castings. If $I^{1} / 2$ per cent of the metal is lost in the melting, how much metal must be melted to furnish the required amount?

A certain grade of paper is sold at the rate of 480 sheets for $\$ 28.00$. How much does this average per sheet? When bought in smaller quantities ro per cent is added to the list price. Find the cost of 240 sheets; of 160 ; of 100 ; of 50 .

"Paying employees" proved to be a fruitful source of problems as well as an interesting topic to the pupils. Attention is directed to the fact that in paying employees, it is customary to give each individual his money in as large denominations as possible. For example, suppose that Smith is to receive $\$ 18.79$; he would be given one $\$$ Io.0o bill, one $\$ 5.00$ bill, one $\$ 2.00$ bill, one $\$$ I.OO bill, one $50 \mathrm{O}$ piece, one $25 \mathrm{c}$ piece and four Ic pieces. In determining the amount of money with which to pay several employees, it is obviously necessary to consider carefully the amount to be drawn from the bank in each denomination; this becomes a good problem from the school point of view.

\section{PLAN FOR GRADE 8A}

For Grade $8 \mathrm{~A}$ two sets of problems were provided: one set is designed for drill upon the essentials at the beginning of the term, and the other set is designed to give additional drill and to correlate with the civics work toward the end of the term. The former consists of problems based upon certain statistics which give the area, population, and wealth of Indianapolis during a term of years; some Indiana problems; and some 
based upon the area, population, and wealth of the United States. The second set consists of problems under the following topics: (a) cost of the Indianapolis schools; (b) cost of the city government of Indianapolis ; $(c)$ money raised by taxes; $(d)$ money raised by the sale of bonds; $(e)$ money raised by special assessments.

The statistics upon which these problems are based were obtained from local, state, or national reports. The problems are designed to give the necessary drill in arithmetic, and to do that in a miscellaneous way; at each point, the main point of interest should be the topic being discussed, not the arithmetical work, but it is obvious that the arithmetical work must be of the very best if the results are to have any meaning. This is exactly the way in which arithmetic is usually applied, and it is certainly desirable that the pupils should have some experience of this kind. But the problems are designed also to give the pupils some acquaintance with the various matters being discussed; this will come about as a result of the constant effort to keep up interest in the topic being considered. The idea of average and per capita are taught in connection with this work. Some of the statistics and some of the questions follow:

COST OF IMPROVEMENTS IN INDIANAPOLIS DURING I89I-I908

Asphalt streets and alleys ........ 58.54 miles... \$3,I68,049.94

Brick streets and alleys .........66.23 miles.... 2,150,242.18

Wooden streets and alleys ........ 22.93 miles.... I,29I,3 I8.47

Bitulithic streets $\ldots \ldots \ldots \ldots \ldots \ldots \ldots .7 .66$ miles... $271_{5}, 085.65$

PROBLEMS

I. Find the cost per mile of each kind of improvement.

2. Find the cost per front foot of each kind.

3. Find the number of miles of streets and alleys paved.

4. Find percentage paved with each kind of pavement.

Under the cost of government, such questions as the following are raised:

I. Find the total expenditures for all purposes in each year (4 years).

2. Find the per capita cost for each year.

3. Find the percentage spent upon permanent improvements.

4. Find the percentage of increase in the per-capita expense from year to year. 
Under the topic "Money Raised by Taxes," an itemized statement of the tax rate for one year is given to show the various funds to which the taxes are distributed, and the portion which each receives. Then additional tables are given to enable the pupils to answer the following questions:

I. Find the total tax rate for city purposes; for state purposes; for city schools; for county purposes.

2. Find the total tax rate for each year in the table.

3. What percentage on the dollar is this?

4. Find the increase in the rate 1900 to 1905 ; 1905 to 1906 ; 1906 to I907; 1907 to 1908.

Under the topic "Money Raised by the Sale of Bonds," it is designed to give the subject of stocks and bonds a local meaning. An itemized statement of the bonded indebtedness of the city is given; attention is called to the limit of indebtedness, and to the margin of legal indebtedness. The bonds issued by the school board are also used as a basis for problems. For example :

I. In 1909 the Board of School Commissioners issued $\$ 50,000$ worth of bonds, receiving $\$ 51,856$ for them. What was the amount of premium? What was the premium on each bond? What was the per cent of premium on each bond?

The bonds bear $3^{1 / 2}$ per cent interest. If you had bought one of these bonds, what would you have paid for it? How much interest would you receive annually? What rate of income would you receive on your investment?

Under the topic "Money Raised by Special Assessments," attention is directed to the manner of computing the sewer assessments in the city, and it is a somewhat complicated problem, involving the computation of the area drained. The manner of computing street assessments also is given. This is a good example of the real purpose of this work; the intention here is that the pupils shall learn how the assessments are computed, not that they shall merely work some arithmetic problems; speaking more generally, the problem material is considered of the maximum importance, the arithmetical work being only a means to the end. 
VIII. PLAN OF COLLECTING AND DISTRIBUTING THE PROBLEMS The material for this work was gathered by a committee of teachers of mathematics, engaged in the seventh and eighth grades, working under the chairmanship of the writer, who was then connected with one of the local high schools; the work at all times received the interest and direction of the administrative officers of the schools. The problems were used in mimeographed form for one year, and were then printed privately by the Indianapolis Board of School Commissioners for free distribution to the pupils of the schools. 